\title{
The Effect of Red Ginger Extract on Reduced Hormone Levels of Prostaglandin and Menstrual Pain Score in Adolescents with Dysmenorrhea
}

\author{
Authors \\ Friska Adiani $^{1 *}$ Hadi $^{2}$, Sri Rahayu ${ }^{1}$, Noor Pramono ${ }^{2}$, Melyana Nurul Widiyawati ${ }^{1}$, \\ Mardiyono \\ ${ }^{1}$ Poltekkes Kemenkes Semarang, Semarang, Indonesia \\ ${ }^{2}$ RSUP dr. Kariadi, Semarang, Indonesia \\ *Coressponding Author \\ Friska Adiani \\ Email:Frisk108aem@gmail.com
}

\begin{abstract}
Background: Dysmenorrhea (pain during menstruation) causes adolescents to experience restrictions on daily activities such as decreased learning concentration and increased absenteeism. One way to handle dysmenorrhea is to use herbal remedies that are red ginger.

Objective: To determine the effect of the red ginger extract on prostaglandin hormone levels and menstrual pain score in the adolescent with dysmenorrhea.

Methods:The design of this study used quasi experiments with a pretest-posttest control group design. With a simple random sampling technique, 36 students were selected from the population, consisting of 18 students in the treatment group given red ginger extract with a dose of 1.5 grams/capsule, $3 x 1$ daily and 18 students in the control group given mefenamic acid with a dose of $500 \mathrm{mg} / \mathrm{capsule} 3 x 1$ daily during first and second menstrual period. Data analysis with paired t test and independent sample t test.

Results: red ginger extract and mefenamic acid significantly reduced prostaglandin hormone levels and menstrual pain scale, and by comparing two interventions, mefenamic acid may decrease prostaglandin hormone levels greater than red ginger extract, $177.35 \mathrm{pg} / \mathrm{ml}$ for Mefenamic acid and $124.55 \mathrm{pg} / \mathrm{ml}$ for red ginger.

Conclusion: red ginger extract can be used as an alternative intervention in treatment of adolescents with dysmenorrhea

Keywords: Dysmenorrhea, Red Ginger, Mefenamic acid, Prostaglandin hormone levels, Menstrual pain score.
\end{abstract}

\section{INTRODUCTION}

Dysmenorrhea is one of the most common gynecological problems. There are two types of dysmenorrhea, namely primary dysmenorrhea and secondary dysmenorrhea. Primary dysmenorrhea is defined as pain or cramps that occur during menstruation in the absence of other gynecological diseases. While secondary dysmenorrhea is menstrual pain caused by gynecological problems such as pelvic abnormalities, endometriosis, pelvic inflammation, adenomyosis, leiomyomata and so forth $^{[1]}$. 
Dysmenorrhea is estimated to occur in $20 \%$ to $90 \%$ of women of reproductive age ${ }^{[2]}$. usually occurs in adolescence with a prevalence of more than $50 \%$ where $10-15 \%$ of them experience severe pain to interfere with activities and daily activities. In Indonesia alone, the incidence of dysmenorrhea is estimated at $54.89 \%$ with severity ranged from mild to severe ${ }^{[3]}$.

Pain during menstruation is also followed by the presence of other symptoms such as diarrhea, nausea and vomiting, weakness, dizziness, headache, and fever ${ }^{[1]}$. In adolescence this leads to limits on daily activities, decreased concentration of learning, increased absence so that achievement is less good in school and if this continues it will have an impact on the economic aspect, where it is estimated that severe dysmenorrhea causes loss of 600 thousand effective working hours or Equivalent to 2 million dollars each year ${ }^{[4]}$.

Nonsteroidal anti-inflammatory drugs (NSAIDs) are commonly used as first-line therapy for women with dysmenorrhea. Ibuprofen, naproxen, mefenamic acid and aspirin have been shown to be effective in dealing with dysmenorrhea ${ }^{[4]}$. However in ${ }^{[5]}$ and ${ }^{[6]}$ research show that this treatment therapy experienced a failure of $20-25 \%$ as well as the side effects of gastrointestinal disturbances, kidney damage and cardiovascular disorders when used in the long term.

Therefore, it is necessary to handling other alternatives with low toxicity in dealing with dysmenorrhea such as red ginger extract where the chemical components contained in red ginger, such as gingerol, shogaol, and zingerone have antiinflammatory and analgesic effects that have been proven by previous studies ${ }^{[6]}$.

\section{METHODS}

\section{Design}

This research is a quantitative research with quasiexperimental research design with two group comparison pretest-posttest design which is done in Dormitory of Poltekkes Semarang and Stikkes Karya Husada, Semarang on January 26, 2017, until March 17, 2017.

\section{Population and sample}

The population in this study were all teenage students who experienced dysmenorrhea in Midwifery Program in Health Polytechnic Kemenkes Semarang and Stikes Karya Husada Semarang as much as 60 female students and by using simple random sampling (lottery method) got 36 students as a sample.

\section{Instrument}

In this study red ginger extract used was obtained from Javaplant Indonesia where the process of extracting using water extraction method while mefenamic acid used is $500 \mathrm{mg}$ mefenamic acid class of patent drugs. The process of weighing and preparation of red ginger extract and mefenamic acid capsules is done at the UNDIP Chemical Laboratory. Red ginger extract capsule weighing 1.5 grams and mefenamic acid capsule weighing 500 mg. Prostaglandin hormone is measured through laboratory testing with Elisa method conducted at GAKI UNDIP Laboratory using blood serum sample of research subjects and menstrual pain score is measured by using Visual Analog Scale (VAS) done twice, ie on the first day of menstruation (pre) And the third day of menstruation (post).

\section{Intervention}

Sample was divided into 2 groups, treatment group as much as 18 respondents were given red ginger extract with dose of each capsule 1.5 gram and given 3 times a day on the first and second day of menstruation while control group as much as 18 respondents were given mefenamic acid with dose ofeach capsule $500 \mathrm{mg}$ and given 3 times a day on the first and second day of menstruation during one menstrual cycle.

\section{Data Analysis}

After normality and homogeneity tests, prostaglandin hormone levels were analyzed by paired sample t test and independent sample t test. While for menstrual pain data using wilcoxon test because the data of menstrual pain is not normally distributed. 


\section{JMSCR Vol||05||Issue||08||Page 26943-26948||August}

\section{Ethical Consideration}

This research has been approved by the ethics committee of Stikkes Karya Husada Semarang with no. 220 / KH.KEPK / KT / III / 2017 and each research subject examined in this study has first received and approved the informed consent from the researcher.

\section{RESULTS}

Table 1 Characteristic Frequency Distributions by Age, Length of Menstrual Cycle, Family History of Dysmenorrhea and Anxiety $(\mathrm{N}=36)$

\begin{tabular}{|c|c|c|c|c|c|c|c|}
\hline \multirow[t]{3}{*}{ Variabel } & \multicolumn{4}{|c|}{ Group } & \multirow[t]{3}{*}{ Total } & \multirow[t]{3}{*}{$\%$} & \multirow[t]{3}{*}{$\mathrm{P}$} \\
\hline & \multicolumn{2}{|c|}{ Treatment } & \multicolumn{2}{|c|}{ Control } & & & \\
\hline & $\mathrm{F}$ & $\%$ & $\mathrm{~F}$ & $\%$ & & & \\
\hline \multicolumn{8}{|c|}{ Age (years) } \\
\hline $17-18$ & 3 & 16,7 & 4 & 22,2 & 7 & 19,4 & 0,730 \\
\hline $19-20$ & 14 & 77,8 & 12 & 66,7 & 26 & 72,2 & \\
\hline$>20$ & 1 & 5,6 & 2 & 11,1 & 3 & 8,3 & \\
\hline Total & 18 & 100 & 18 & 100 & 8 & & \\
\hline \multicolumn{8}{|c|}{$\begin{array}{l}\text { Length of menstrual } \\
\text { cycle (days) }\end{array}$} \\
\hline$<28$ & 1 & 5,6 & 2 & 11,1 & 3 & 8,3 & \\
\hline $28-30$ & 15 & 83,3 & 16 & 88,9 & 31 & 86,1 & 0,306 \\
\hline$>30$ & 2 & 11,1 & 0 & 0 & 2 & 5,6 & \\
\hline Total & 18 & 100 & 18 & 100 & 36 & & \\
\hline \multicolumn{8}{|c|}{$\begin{array}{l}\text { Family history of } \\
\text { dysmenorrhea }\end{array}$} \\
\hline Yes & 9 & 50 & 10 & 55,6 & 19 & 52,8 & \\
\hline No & 9 & 50 & 8 & 44,4 & 17 & 47,2 & \\
\hline Total & 18 & 100 & 18 & 100 & 36 & & 0,738 \\
\hline \multicolumn{8}{|l|}{ Axiety } \\
\hline mild & 10 & 55,6 & 11 & 61,1 & 21 & 58,3 & \\
\hline moderate & 8 & 44,4 & 7 & 38,9 & 15 & 41,7 & \\
\hline Total & 18 & & 18 & 100 & 36 & & 0,735 \\
\hline
\end{tabular}

*Homogenitas test

Based on table 1 above, it was found that all variables (age, length of menstrual cycle, family history of dysmenorrhea and axiety) were have $\mathrm{p}$ value $>0,05$ These means there is no difference in variance between both groups(treatment and control) in age, length of menstrual cycle, family history of dysmenorrhea and axiety.

Table 2 Differences in Prostaglandin Hormone Levels Before and After Administration of Red Ginger Extract and Mefenamic Acid

\begin{tabular}{lccccc}
\hline Variabel & \multicolumn{2}{c}{ Pre } & \multicolumn{2}{c}{ Post } & P \\
\cline { 2 - 4 } & Mean & SD & Mean & SD & \\
\cline { 1 - 4 } $\begin{array}{l}\text { Prostaglandin } \\
\text { hormone levels }\end{array}$ & & & & & \\
Treatment & 03,32 & 73,33 & 178,77 & 58,71 & 0,000 \\
Control & 04,56 & 73,50 & 127,21 & 50,89 & 0,000
\end{tabular}

*Paired Sample t-test
Based on table 2 above, it was found that the mean of prostaglandin level in treatment group before given red ginger was $303,32 \mathrm{pg} / \mathrm{ml}$, mean after giving red ginger (treatment group) that is 178,77 $\mathrm{pg} / \mathrm{ml}$ with $\mathrm{p}$ value $=0,000$. These data indicate that there are significant differences in mean levels of prostaglandin hormone before and after administration of red ginger extract.

In the control group, the mean prostaglandin hormone level before giving mefenamic acid was $304,56 \mathrm{pg} / \mathrm{ml}$, mean after giving mefenamic acid was $127,21 \mathrm{pg} / \mathrm{ml}$ with $\mathrm{p}=0,000$. These data suggest that there is a significant difference in mean levels of prostaglandin hormone before and after the administration of mefenamic acid.

Table 3 Differences in Menstrual Pain Score Before and After Administration of Red Ginger Extract and Mefenamic Acid

\begin{tabular}{llllll}
\hline Variabel & Pre & \multicolumn{4}{c}{ Post } \\
\cline { 2 - 6 } & Med & $\begin{array}{l}\text { Max- } \\
\text { Min }\end{array}$ & Med & $\begin{array}{l}\text { Max- } \\
\text { Min }\end{array}$ & P \\
\hline Menstrual Pain Scale & & & & & \\
Treatment & 6,5 & $9-5$ & 2 & $9-5$ & 0,000 \\
Control & 6,5 & $3-0$ & 1 & $3-0$ & 0,000 \\
\hline *Wilcoxon test & & & & &
\end{tabular}

Based on table 3, median of menstrual pain score before giving red ginger extract in treatment group was 6,5 median after given red ginger extract on control group was 2 with $\mathrm{p}$ value 0.000 . These data show that there is a significant difference in median menstrual pain score before and after administration of red ginger extract. The menstrual pain score in the control group before given mefenamic acid was 6,5 rmedian after administered mefenamic acid was 1 with $\mathrm{p}$ value $<0,000$. These data indicate that there is a significant difference in median menstrual pain score before and after administration of mefenamic acid in the control group.

Table 4 The Effect of Red Ginger Extract and Mefenamic Acid on Prostaglandin Hormone Level and Mesntrual Pain Scale

\begin{tabular}{lccccc}
\hline Variabel & \multicolumn{2}{c}{ Treatment } & \multicolumn{2}{c}{ Control } & P \\
\cline { 2 - 5 } & Mean & SD & Mean & SD & \\
\hline $\begin{array}{l}\text { Prostaglandin } \\
\text { Hormone Levels }\end{array}$ & 124,55 & 100,36 & 177,35 & 75,51 & 0,083 \\
\hline *Independent Sample t Test & & & & & \\
\hline
\end{tabular}


Table 4 shows that $\mathrm{p}$ value of Prostaglandin hormone levels was 0,083 ( $p$ value $>0,05)$ that means there was no significant difference in prostaglandin hormone levels between respondent who given red ginger extract (treatment group) and given mefenamic acid (control group). However, based on mean values, the data showed that respondents in control group who given mefenamic acid have lower mean value than respondents in treatment group who given red ginger extract $(177,35 \mathrm{pg} / \mathrm{ml}$ for control group and $124,55 \mathrm{pg} / \mathrm{ml}$ for treatment group).

Table 5 The effect of red ginger on menstrual pain score

\begin{tabular}{lccccc}
\hline Variabel & \multicolumn{2}{c}{ Treatment } & Control & \\
\cline { 2 - 5 } & Med & Max-Min & Med & x-Min & P \\
\hline
\end{tabular}

$\begin{array}{llllll}\text { Menstrual Pain Scale } & 2 & 3-0 & 1 & 3-0 & 0,010\end{array}$

*mann whitney Test

Table 5 shows that $p$ value of menstrual pain score was 0,010 ( $\mathrm{p}$ value $<0,05$ ) that means there was significant difference in menstrual pain score between respondents who given red ginger extract (treatment group) and given mefenamic acid (control group). wheareas, based on median values, the data showed that respondents in control group who given mefenamic acid have lower median value than respondents in treatment group who given red ginger extract ( 2 for treatment group and $1 \mathrm{pg} / \mathrm{ml}$ for control group).

\section{DISCUSSION}

The results show that red ginger extract can significanly reduced prostaglandin hormone levels and pain score(table 2 and table 3 ) and based on table 4 that compare the red ginger extract and mefenamic acid, this two intervention didn't have significant difference in reduced prostaglandin hormone levels with $\mathrm{p}$ value $>0,05(0,08)$. But in menstrual pain score, mefenamic acid have better results than red ginger extract with lower median menstrual pain score (table 5).

Red ginger can reduced prostaglandin hormon because ginger contains substances that inhibit the bio synthesis of prostaglandin (PG synthesis), namely gingerols and diarylheptanoids [7], [9]. The mechanism of action of both substances indicates that these substances also inhibit the biosynthesis of leukotriene (LT), namely arachidonate 5lipoxygenase. Diarylheptanoids are the most active substance component in ginger in inhibiting the formation of 5-lipoxygenase ${ }^{[7],[10]}$.

This is in line with research conducted in Teheran which proves that ginger administration for 5 days in respondents has a markedly lightening effect in terms of intensity and duration of pain felt by the respondents. Research subjects were given ginger in the form of ginger powder with a dose of $500 \mathrm{mg}, 3$ times daily for 5 days ${ }^{[6]}$.

Other studies have also shown that red ginger has the same effectiveness as mefenamic acid and ibuprofen in relieving pain in primary dysmenorrhea $^{[5]}$. In this study the intervention was given to group 1 , which was given ginger powder with a dose of $250 \mathrm{mg} 4$ times daily for 3 days from the first day of menstruation, group 2 received 250 $\mathrm{mg}$ of mefenamic acid 4 times daily for 3 days starting from the first day of menstruation and Group 3 received $400 \mathrm{mg}$ of ibuprofen 4 times daily for 3 days starting from the first day of menstruation $^{[5]}$.

Anti-inflammatory effects of ginger due to its active components, namely gigerol, gingerdione and zingeron inhibit prostaglandins by inhibiting cyclooxygenase enzymes. In addition ginger is able to inhibit lipoksigenase enzyme ${ }^{[11-13]}$. It will result in a decrease in leukotrienes and prostaglandins that are mediators of inflammation. The effect is similar to the anti-inflammatory effect of mefenamic acid and ibuprofen which is a class of NSAIDs ${ }^{[14]}$.

Phenol compounds in oleoresin have been shown to have anti-inflammatory effects and are known to reduce muscle tension while essential oils in ginger are useful compounds for reducing pain, as an antiinflammatory and good bacterial eradication [9]. Bioactive compounds in red ginger, gingerol and shogaol can function as antioxidants because of their ability to stabilize free radicals by giving hydrogen atoms quickly to free radicals. One mechanism in reducing inflammation is to release 
macrophages as an inflammatory response. The released macrophages produce ROS (reactive oxygen species) which will increase the damage and increase the pain. The antioxidant properties possessed by phenolic compounds such as gingerol and shogaol can neutralize ROS so as to reduce damage and reduce pain ${ }^{[15]}$.

The results of this study differ from some studies that suggest that red ginger has the same effectiveness as mefenamic acid and ibuprofen in reducing pain in primary dysmenorrhea ${ }^{[5]}$. It is because of the differences of doses and species of ginger that used and in pain assassment while measure menstrual pain. Beside that some limitations in this study such as a small sample size, and used dysmenorrhea as an general (not specific if it's primary or secondary dysmenorrhea also have an impact).

\section{CONCLUSSION}

Red ginger can be used as an alternative treatment in dealing with dysmenorrhea where red ginger can reduce levels of prostaglandin hormone and menstrual pain scale significantly. Further studies regarding the efficiancy and savety of various doses and treatmen durations of ginger and the exact mechanism of action are warranted.

\section{REFERENCES}

1. Lefebvre G, Pinsonneault O, Antao V, Black A, Burnett M, Feldman K, et al. Primary dysmenorrhea consensus guideline. SOGC clinical practice guideline. JOGC. 2005.

2. Osayande, SA and Mehulic, S., Diagnosis and Initial Management of Dysmenorrhea. American Academy of Family Physicians. 2014; 89(5):341-346.

3. Qittun. Menurunkan intensitas nyeri menstruasi (dysmenorrhea) dengan terapi musik mozart. (internet). Available from: http://qittun.blogspot.com/2008/09/menurun kan-intensitas-nyeri-menstruasi.html.2008. [In Indonesia]

4. George, S Nayana., Priyadarshini, S., \& Shetty, S. Dysmenorrhoea Among
Adolescent Girls Chaacteristics and Symptoms Experienced During Menstruation. Nitte University Journal of Health Science. 2014; 4(3): 45-52.

5. Ozgoli, G., Goli, M. Moattar F. Comparison of effects of ginger, mefenamic acid and ibuprofen on pain in women with primary dysmenorrhea. 2009.

6. Haghighi M, Khalvat A, Toliat T, Jallaei S. Comparing the effects of ginger (zingiber officinale) extract and ibuprofen on patients with osteoarthritis. Archives of Iranian Medicine. 2005

7. Malhotra, S \& Singh PA. Medicinal Properties of Ginger (Zingiber officinale Rosc). Natural Product Radiance Vol 2 (6). 2003.

8. Jenabi E. The Effect of Ginger for relieving of Primary Dysmenorrhea. Journal of Pakistan Medical Association. 2013; 63: 8.

9. Kashefi, F., Khajehei, M., Cher T, Mahbubeh., Alavinia, M.., Asili, J. Comparison of the effect of ginger and zinc sulfate on primary dysmenorrhea: a placebo-controlled randomized trial. Researchgate. 2012.

10. Fathona D. Kandungan gingerol dan shogaol, intensitas kepedasan dan penerimaan panelis terhadap oleoresin jahe gajah (zingiber officinale var. Roscoe), jahe emprit (zingiber var amarum) dan jahe merah (zingiber officinale var rubrum). Fakultas teknologi pertanian IPB: Bogor. 2011.

11. Tim Lentera. Khasiat dan manfaat jahe merah : si rimpang ajaib (Jakarta): Agromedia Pustaka; 2002.

12. Hernani, Winarti. C. Kandungan bahan aktif jahe dan pemanfaatannya dalam bidang kesehatan (Bogor): Balai Penelitian Tanaman Obat dan Aromatik; . 2011.

13. Kusumaningati RW. Analisis kandungan fenol total jahe secara in vitro. Fakultas kedokteran Universitas Indonesia: Jakarta. 2009 
14. Black CD, Herring MP, Hurley DJ, O'Connor PJ. Ginger (zingiber officinale) reduces muscle pain caused by eccentric exercise. The journal of pain. 2010

15. Wresdiyati T, Astawan M, Adnyane IKM. Aktivitas anti inflamasi oleoresin jahe (zingiber officinale) pada ginjal tikus yang mengalami perlakuan stress. Jurnal teknologi dan industri pangan. 2003. 